\title{
STRUCTURE AND TREE DIVERSITY PATTERNS AT THE LANDSCAPE LEVEL IN A MEXICAN TROPICAL DECIDUOUS FOREST
}

\author{
Elvira Durán ${ }^{1,2,6}$, Jorge A. Meave ${ }^{3}$, Emily J. LotT ${ }^{4}$ and Gerardo SeGura ${ }^{5}$ \\ ${ }^{1}$ Centro Interdisciplinario de Investigación para el Desarrollo Integral Regional, Unidad Oaxaca, Instituto \\ Politécnico Nacional, Calle Hornos 1003, Sta. Cruz Xoxocotlán 71230, Oaxaca, Mexico. \\ ${ }^{2}$ Unidad Académica de Geografía, Instituto de Geografía, Universidad Nacional Autónoma de México, \\ Aquiles Serdán 382, Morelia 58000, Michoacán, Mexico. \\ ${ }^{3}$ Departamento de Ecología y Recursos Naturales, Facultad de Ciencias, Universidad Nacional \\ Autónoma de México, México 04510, D.F., Mexico. \\ ${ }^{4}$ Plant Resources Center, University of Texas at Austin, Austin, TX, 78712, USA \\ ${ }^{5}$ The World Bank, 1818 H Street NW, Washington, DC 20433, USA \\ ${ }^{6}$ Author for correspondence: CIIDIR-Oaxaca, IPN. Phone: +52 (951) 517-06-10 Ext. 82748; \\ e-mail: eduran3@hotmail.com
}

\begin{abstract}
Landscape level variability of structure and tree species diversity was analyzed in a tropical deciduous forest at Chamela, Mexico. Trees with DBH $\geq 5 \mathrm{~cm}$ were sampled in 210.24 ha plots (5.04 ha in total) distributed among six different morpho-pedological land units. Average density was 1,385 individuals ha-1, basal area $15.9 \mathrm{~m} 2 \mathrm{ha}^{-1}$, and canopy height $6.8 \mathrm{~m}$. Trunks with DBH $\leq 14 \mathrm{~cm}$ accounted for $90 \%$ of the entire set. A total of 148 species, 102 genera, and 43 families were recorded. Seventy percent of all species were poorly represented $\left(<10\right.$ individuals ha $\left.{ }^{-1}\right)$. A Principal Component Analysis (PCA) based on structure and diversity variables showed that plots from the same morpho-pedological land unit were not always located close to each other along the two first axes, but a further PCA based on dominant species clearly divided two groups of plots. Although canopy structure and tree species diversity varied continuously across the landscape, $\beta$-diversity (evaluated through species similarity between plot pairs) and the identities of dominant species exhibited the clearest distinction. The dichotomy between granitic vs. non-granitic lithology was the condition most clearly related with a lower similarity in species composition and the strongest contrast in the dominant species group.
\end{abstract}

Key words: Chamela, lithology, mesoscale, Mexico, morpho-pedological land units, species composition, tree community.

Resumen: La variabilidad a nivel de paisaje de la estructura y la composición de especies fue analizada en el bosque tropical caducifolio de Chamela, México. Se registraron todos los árboles con DAP $\geq 5 \mathrm{~cm}$ presentes en 21 parcelas de 0.24 ha (5.04 ha en total) distribuidas en seis unidades morfopedológicas diferentes. En promedio, la densidad fue de 1,385 individuos ha ${ }^{-1}$, el área basal de $15.9 \mathrm{~m}^{2} \mathrm{ha}^{-1}$ y la altura promedio del dosel fue $6.8 \mathrm{~m}$. La mayoría $(90 \%)$ de los troncos tuvieron un DAP $\leq 14 \mathrm{~cm}$. En total se registraron 148 especies, 102 géneros y 43 familias de árboles. Más de $70 \%$ de las especies estuvieron pobremente representadas $\left(<10\right.$ árboles ha $\left.^{-1}\right)$. Un análisis de componentes principales basado en atributos estructurales y de diversidad mostró una pobre relación entre las parcelas de una misma unidad morfopedológica, pero el mismo tipo de análisis, basado en las especies dominantes, segregó a las parcelas en dos grupos. Aunque la estructura y la diversidad de especies cambiaron de forma continua en el paisaje, la diversidad beta (evaluada a través de la similitud de especies entre pares de parcelas) y el grupo de especies dominantes mostraron los mayores contrastes. Tales diferencias estuvieron claramente asociadas a diferencias en la litología (granito vs. no-granito).

Palabras clave: Chamela, composición de especies, comunidad de árboles, litología, mesoescala, México, unidades morfopedológicas.

C haracterization of the structure and species composition of tree communities is the first step in understanding forest ecology and dynamics. For example, such information has been useful for comparing and understanding historical and ecological relationships among forests (Ashton et al., 2004). Data on tree species distribution also allow to unravel complex concepts and develop models on plant communities and their spatial patterns (Connell, 1978; Hubbell, 2001; Wright, 2002; Chase, 2005). The analysis of tree community structure and diversity is still challenging for researchers in tropical ecology (Bawa et al., 2004; Losos et al., 2004).

Traditionally, studies focused on tree communities had placed more emphasis on tropical humid forests (Richards, 
1996), whereas tropical deciduous forests (TDFs) have received much less attention, despite their widespread occurrence in the inter-tropical belt (Murphy and Lugo, 1986; Bullock et al., 1995). Nowadays, TDFs are becoming better studied, but basic knowledge about their structure and tree diversity patterns at the landscape level is still lacking. Moreover, detailed analyses on tree community structure and diversity in tropical forests have been commonly conducted at local scales (a few hectares or less), including the notorious efforts in "large" plots $(\geq 16-50 \mathrm{ha}$; Campbell, 1994; Losos et al., 2004). In contrast, relatively few analyses are available at the mesoscale (hundreds of hectares to dozens of squared kilometers, sensu Delcourt and Delcourt, 1988).

At the mesoscale or landscape level, either through direct observation or by remote sensing tools, undisturbed tropical forests appear to exhibit homogeneous canopies (Campbell, 1994; Richards, 1996; Kalacska et al., 2004). However, vegetation and plant community ecologists agree in that tree canopies regularly comprise a mixture of different structural and compositional patches (Cleef et al., 1982; Rzedowski, 1986; Gentry and Ortiz, 1993; Condit, 1996; Ricklefs, 2000). Therefore, the analysis of the degree of structural and compositional heterogeneity in tropical landscapes is of paramount importance. Landscape level studies in tropical forests have documented spatial patterns in plant communities and explored their ecological relationships with physical factors, including geomorphology, soils, landforms, elevation and lithology. However, the heterogeneity of these factors is sometimes difficult to examine at smaller spatial scales (Duivenvoorden and Lips, 1994; Clark et al., 1995; Condit, 1996; Tuomisto et al., 1995; Vázquez-G. and Givnish, 1999; Villers et al., 2003; Pérez-García and Meave, 2004). These studies indicate that an initial survey of the physical environmental mosaic may suggest differences between habitats, allowing to put forward preliminary hypotheses on the relationships between vegetation patterns and the physical environment (Campbell, 1994; Wright, 2002). Knowledge of a landscape's physical environment may also help locate vegetation samples and orient the discussion of results (Chazdon, 1996; Ricklefs, 2000).

Among Mexican TDFs, the ecosystem of Chamela (Jalisco State, Mexico), is one of the best known, because numerous patterns and processes have been studied there during more than three decades (Maass et al., 2005). Particularly, tree community patterns have been described through rapid assessment procedures (Lott et al., 1987), by detailed analyses in small-watersheds (Galicia et al., 1999; Balvanera et al., 2002; Segura et al., 2003), and through meticulous review of data from different studies (Durán et al., 2002). However, until now an examination of structure, species composition and diversity patterns at the landscape level is lacking. Thus, based on previous studies of the dif- ferent morpho-pedological land units (Cotler et al., 2002; Durán, 2004), here we aimed at describing and analyzing tree community patterns in the TDF of Chamela. We addressed two questions: How much does structure in the tree community vary across the landscape? How is tree species diversity organized within a mosaic of different morpho-pedological land units?

\section{Materials and methods}

Study Site. The study site was the Chamela Biological Field Station, which belongs to the Universidad Nacional Autónoma de México. It is located near the Pacific coast of Jalisco State, western Mexico. The climate, according to García's (1988) modification of Köppen's system, is the driest among tropical humid climates (Awo). Mean annual temperature and precipitation are $24.9^{\circ} \mathrm{C}$ and $748 \mathrm{~mm}$, respectively. A strong seasonality is observed, with $88 \%$ of annual precipitation falling between June and October (Bullock, 1986). In the 1,600 ha study area, 14 morphopedological land units were identified (figure 1; Cotler et al., 2002; Durán, 2004). Tropical deciduous forest (TDF) dominates the landscape and is present in 11 out of the 14 land units, with the vegetation cover in the remaining units being tropical subdeciduous forest (Durán et al., 2002).

Tree community characterization. The tree community (DBH $\geq 5 \mathrm{~cm}$ ) was studied in 21 plots of 0.24 ha each (30 $\times 80 \mathrm{~m}$ ). Plots were distributed among the six largest and most contrasting morpho-pedological land units with TDF (figure 1): (1) SAG: Summit areas on granite, (2) SAT: Summit areas on tuffs, (3) LSG: Low rectilinear slopes on granite, (4) ISG: Intermediate rectilinear slopes on granite, (5) HSG: High rectilinear slopes on granite, and (6) SACG: Summit areas with conglomerates cover on granite. In each land unit, the plots were established in similar slope and soil depth conditions.

Individual trunks were counted and their DBH measured. Canopy height was measured in each plot along two $80 \mathrm{~m}$ parallel transects, with 42 point readings taken at $2 \mathrm{~m}$ intervals with an optical range finder. Species level taxonomic identities were recorded in situ; in case of doubt identification was confirmed by comparison of tree samples with herbarium specimens.

Data analysis. Structure and diversity descriptive parameters were compared between the six morpho-pedological land units with non-parametric Kruskal-Wallis tests (Siegel and Castellan, 1995). Diversity was assessed through species richness and Shannon (base e) and Simpson indices (Magurran, 1990). Comparisons of shared species between pairs of plots ( $\beta$-diversity), were made by calculating the quantitative version of Sørensen similarity index, which is less sensitive to very abundant species (Magurran, 1990; 
TREE COMMUNITY STRUCTURE AND DIVERSITY IN A TROPICAL DECIDUOUS FOREST LANDSCAPE
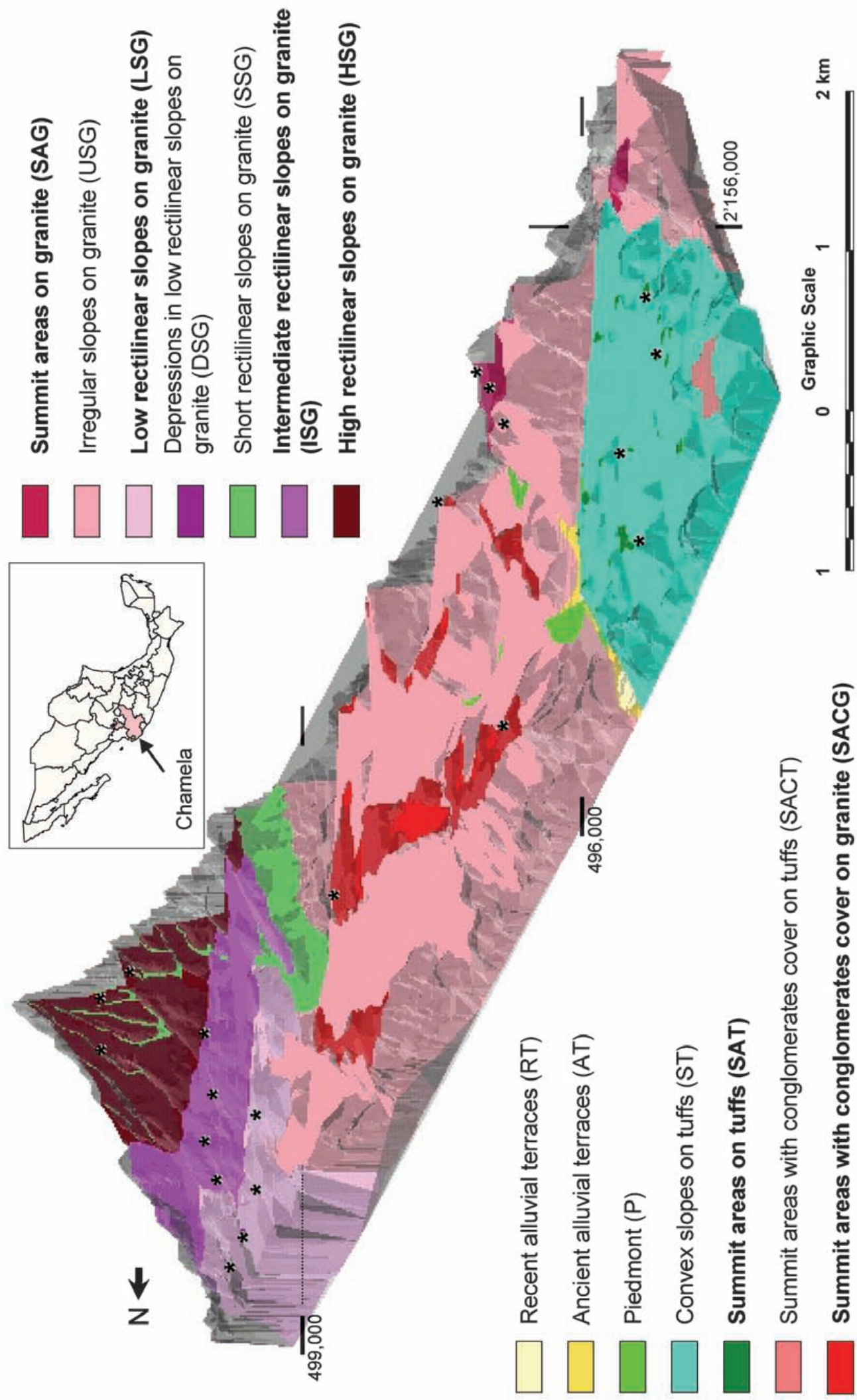

ভ্ত

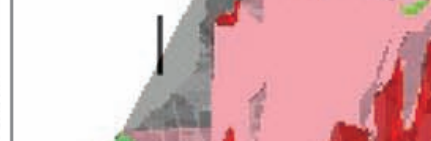

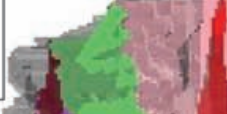
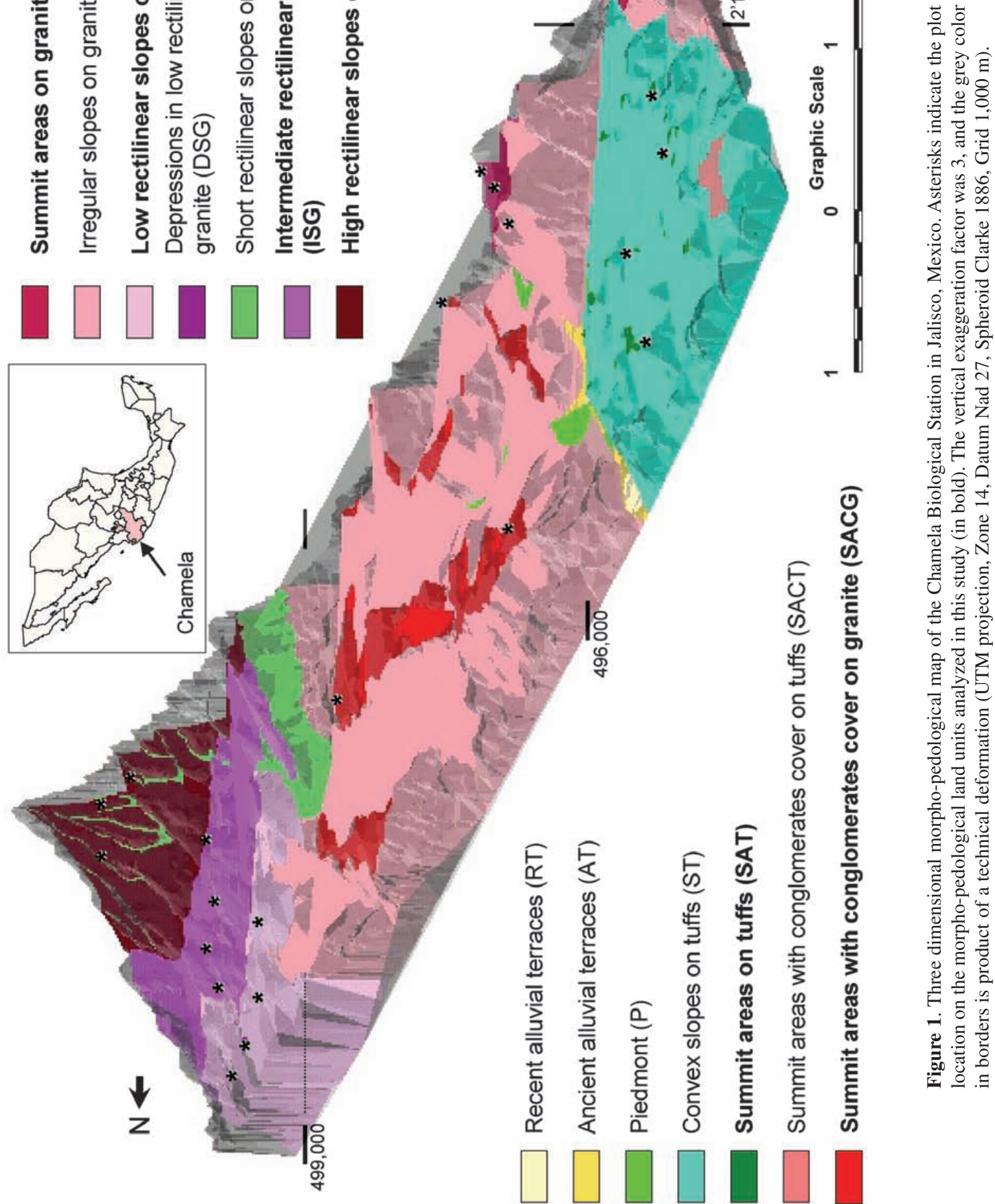
Moreno, 2001). Species abundances were used, according to the following formula:

$$
\text { Sørensen index }=\frac{2 \mathrm{jN}}{(\mathrm{aN}+\mathrm{bN})}
$$

where $\mathrm{jN}=$ sum of the lowest abundance values of each pair of species shared by the two plots, $\mathrm{aN}=$ total number of individuals in plot $\mathrm{A}$, and $\mathrm{bN}=$ total number of individuals in plot B. Four similarity categories were defined based on this index: low $(\leq 0.25)$, moderate $(>0.25-0.50)$, high $(>0.50-0.75)$, and very high $(>0.75)$. Frequency distributions in these categories were compared through Kruskal-Wallis tests (Siegel and Castellan, 1995); the number of species shared in plot pairs and similarity values for plot pairs located in the same and in different lithologies were compared by $t$-tests.

Species and family dominance was determined by plot, by morpho-pedological land unit, and for all plots combined. Percent dominance was estimated by using the equation:

relative density $(\%)+$ relative basal area $(\%)$

$\%$ dominance $=\frac{}{2}$

Completeness of the tree richness representation in the landscape was assessed by drawing cumulative speciesarea curves derived from the non-parametric Chao 1 model (Colwell, 2000), which uses species abundances for making the prediction (Moreno, 2001). Cumulative frequency was the mean value of 50 iterations for each morpho-pedological land unit (three or four increments) and for the entire study ( 21 increments). Observed and estimated species richness were compared through $\chi^{2}$ tests (Siegel and Castellan, 1995).

Principal Component Analysis (PCA) was used to analyze the variation in structure and species composition among morpho-pedological land units (Jongman et al., 1994). One PCA used a matrix with 15 structural variables per plot (number of trees, number of stems, mean DBH, standard deviation of $\mathrm{DBH}$, total basal area, mean height, standard deviation of height, number of multi-stemmed trees, percent proportion of multi-stemmed trees, sum of importance values of the five most dominant species, Shannon index, Simpson index, number of species, number of genera, and number of families). A second PCA was performed based on a matrix containing percent dominance values of the ten most dominant species in each plot (63 species in total). Differences between plot scores on the first two Principal Components, when plots were grouped by morpho-pedological land units and by lithology (granite $v s$. non-granite) were compared through Mann-Whitney tests.

\section{Results}

Structure, diversity and species composition. Tree community structure was highly variable within and among morpho-pedological land units (table 1a). Mean density for the 21 plots was 1,385 individual trees ha ${ }^{-1}$ (range: $804-$ 2,117 trees $\mathrm{ha}^{-1}$ ). SAG plots had the largest tree density; however, basal area in them was lower than in other land units where densities were lower (SAT, SACG, and LSG). These differences are related to the frequencies in $\mathrm{DBH}$ classes. Trunks with $\leq 14 \mathrm{~cm} \mathrm{DBH}$ accounted for $90 \%$ of the total (figure 2a). SAT, SACG, and LSG land units showed similar relative frequencies in the $\geq 5-14( \pm 85 \%)$ and $\geq 15-24( \pm 10 \%)$ DBH classes; in contrast, SAG and ISG land units had the most slender trunks. Overall, trunks with $\geq 25 \mathrm{~cm} \mathrm{DBH}$ were infrequent $(2.5 \%)$. Although some trees reached heights of $17 \mathrm{~m}$, more than $61 \%$ of the 1,722 canopy height readings ranged between 5 and $9 \mathrm{~m}$, and $4 \%$ of them were $\leq 2 \mathrm{~m}$ (figure 2c). Mean canopy height for the 21 plots was $6.82 \mathrm{~m}( \pm 1.99$, S.D. $)$. Only for SAG mean height was shorter $(5.9 \mathrm{~m})$ than the overall mean, but it displayed a larger coefficient of variation (36.6\%) than the other land units. In addition, the proportion of multistemmed trees was similar on granite land units (SAG, LSG, ISG, HSG), where it was around $15 \%$, but in plots on non-granite lithology (tuffs and conglomerates) this condition was observed in about $20 \%$ of trees (table 1a). Significant differences in the proportion of multi-stemmed trees were found between plots on granite and non-granite lithology $(\mathrm{U}=21, P<0.05)$.

In total, 42 families, 102 genera and 148 species were recorded (table 1b). Maximum and minimum values showed that richness at family, genera and species level, as well as diversity indices, were highly variable among plots. There were no significant differences in tree diversity between morpho-pedological land units $(\mathrm{U}=5, P=0.05)$, even though extreme diversity values were found in SACG and HSG. Families with the largest genera and species richness were Leguminosae, Euphorbiaceae and Rubiaceae (figure $3 \mathrm{a}, \mathrm{b}$; appendix 1). The three most speciose genera were Lonchocarpus, Bursera, and Caesalpinia, which together accounted for $28 \%$ of total species richness (figure $3 c)$. The families/genera (1:2.4), families/species (1:3.5), and genera/species $(1: 1.4)$ ratios indicate that genera richness is relatively large in the canopy of Chamela's TDF. Most families, genera and species were poorly represented, despite their important contributions to richness. Species composition and abundance were variable among plots and morpho-pedological land units, and no single species occurred or was dominant in all land units (table 2; appendix 1). When data for all plots were combined, Caesalpinia eriostachys emerged as the most dominant species (importance value of $12.5 \%$ ). 

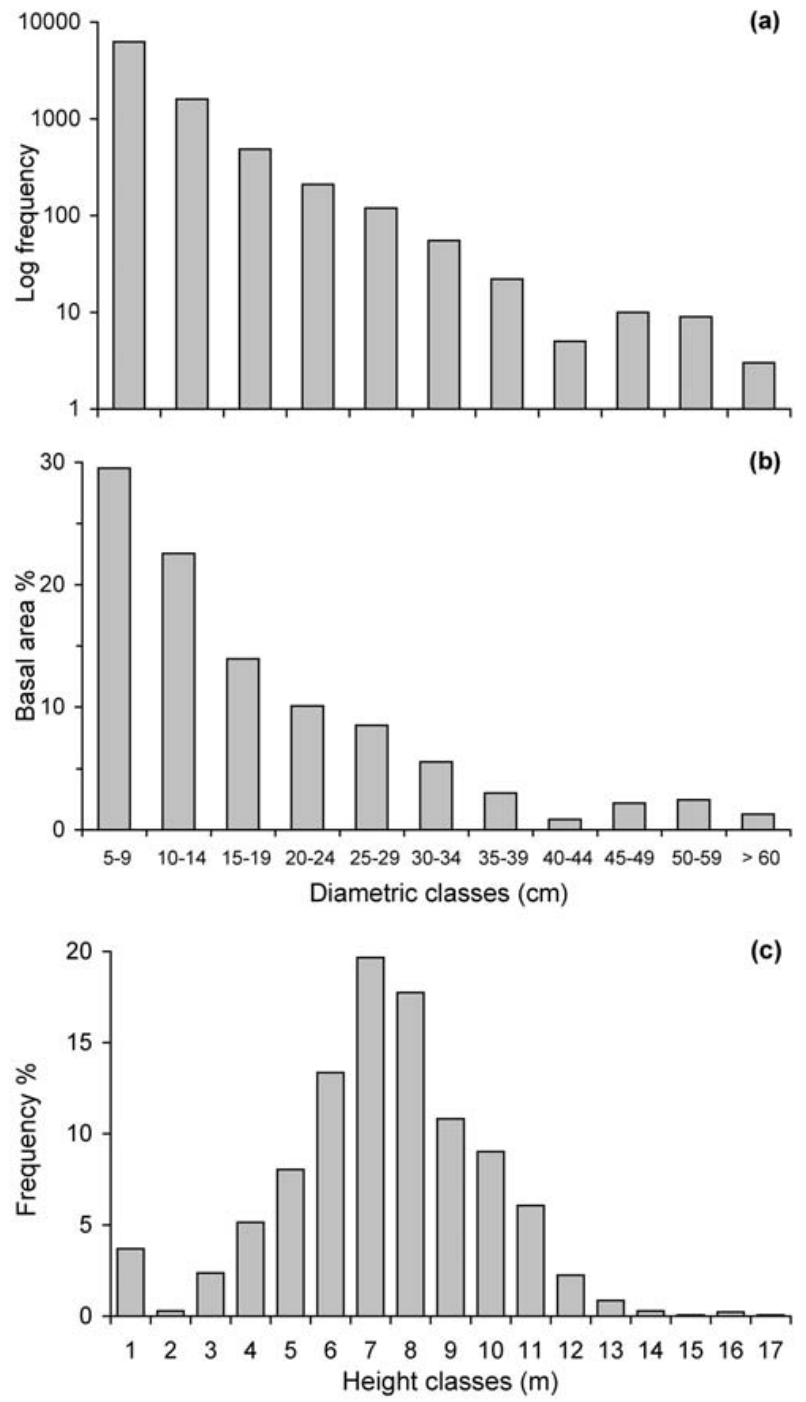

Figure 2. Structure of the tree component of Chamela's TDF. (a) Frequency distribution in diameter classes. (b) Percent distribution of basal area among diameter classes. (c) Frequency distribution of canopy height readings.

Spatial organization. Species-area curves suggested that a large proportion of the tree species richness of Chamela's TDF was represented in the five hectares covered by this study (figure 4a, b). However, it is likely that there are more tree species, given the significant differences between the observed and estimated species richness from the curves based on all 21 plots $\left(\chi^{2}=35.75, P<0.05\right)$. Particularly, the number of species may be larger in the four land units for which significant differences $(P<0.05)$ between observed and estimated species richness were obtained (SAT, $\chi^{2}=$ 7.98; SACG, $\chi^{2}=11.08 ;$ LSG, $\chi^{2}=18.31 ;$ HSG, $\chi^{2}=$
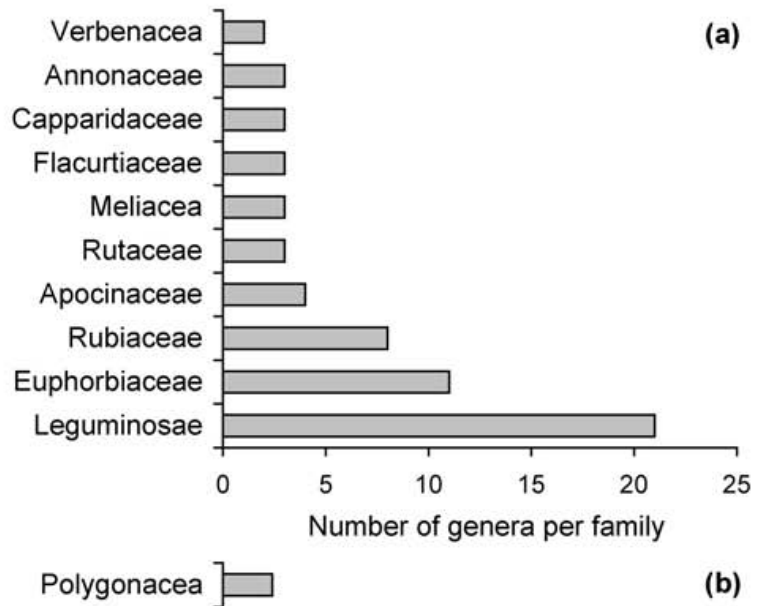

Flacurtiaceae

Capparidaceae

Apocinaceae

Burseracea

Boraginaceae

Rutaceae

Rubiaceae

Euphorbiaceae

Leguminosae
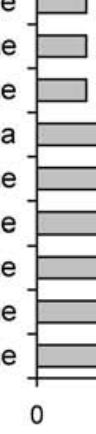

(b)

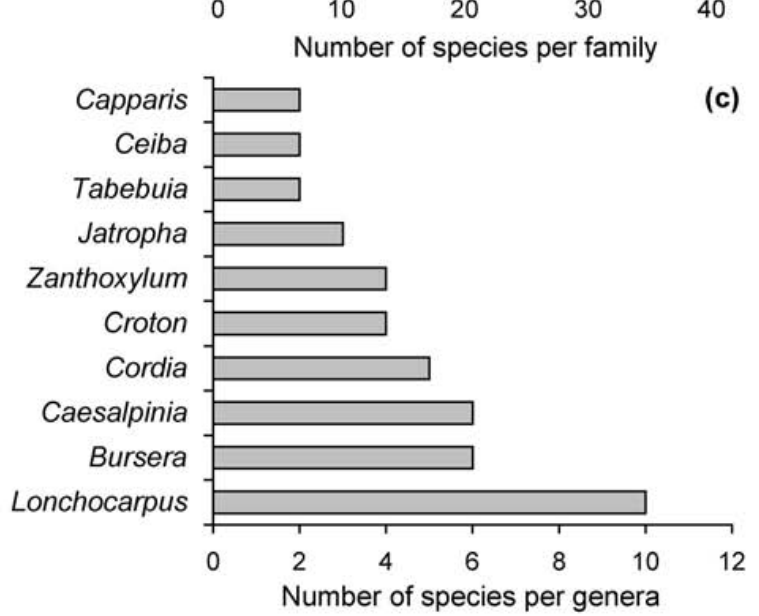

Figure 3. (a) Distribution of genera among the most important families. (b) Distribution of species among families. (c) Distribution of species among genera. 
Table 1. Synthesis of tree community structure and diversity variables for the total sample (5.04 ha) and for the six analyzed morpho-pedological land units. Mean values include standard deviations, in parenthesis. Abbreviations: SAG = Summit areas on granite; SAT $=$ Summit areas on tuffs; SACG = Summit areas with conglomerates cover on granite; LSG = Low slopes on granite; ISG = Intermediate slopes on granite; HSG = High slopes on granite.

\begin{tabular}{|c|c|c|c|c|c|c|c|c|c|}
\hline & \multicolumn{3}{|c|}{ All Plots } & \multicolumn{6}{|c|}{ Morpho-pedological land units } \\
\hline & Total & $\begin{array}{l}\text { Mean } \\
\text { (S.D.) }\end{array}$ & Range & SAG & SAT & SACG & LSG & ISG & HSG \\
\hline \multicolumn{10}{|l|}{ (a) Structure } \\
\hline Density (trees ha-1) & & $\begin{array}{l}1,386 \\
(347)\end{array}$ & $804-2,117$ & $\begin{array}{c}1,772 \\
(92)\end{array}$ & $\begin{array}{l}1,163 \\
(250)\end{array}$ & $\begin{array}{c}1,307 \\
(111)\end{array}$ & $\begin{array}{l}1,297 \\
(512)\end{array}$ & $\begin{array}{l}1,347 \\
(204)\end{array}$ & $\begin{array}{l}1,543 \\
(499)\end{array}$ \\
\hline $\mathrm{DBH}(\mathrm{cm})$ & & $\begin{array}{c}9.4 \\
(1.3)\end{array}$ & $5-72$ & $\begin{array}{c}8.5 \\
(3.6)\end{array}$ & $\begin{array}{l}10.1 \\
(6.6)\end{array}$ & $\begin{array}{c}9.9 \\
(5.3)\end{array}$ & $\begin{array}{l}10.3 \\
(6.5)\end{array}$ & $\begin{array}{c}8.2 \\
(3.6)\end{array}$ & $\begin{array}{c}9.3 \\
(4.6)\end{array}$ \\
\hline Basal area $\left(\mathrm{m}^{2} \mathrm{ha}^{-1}\right)$ & & $\begin{array}{l}15.9 \\
(5.3)\end{array}$ & $6.7-27.6$ & $\begin{array}{l}14.8 \\
(4.2)\end{array}$ & $\begin{array}{l}17.6 \\
(3.5)\end{array}$ & $\begin{array}{l}17.1 \\
(3.8)\end{array}$ & $\begin{array}{l}18.8 \\
(8.9)\end{array}$ & $\begin{array}{l}10.7 \\
(4.4)\end{array}$ & $\begin{array}{l}16.4 \\
(2.6)\end{array}$ \\
\hline Canopy height (m) & & $\begin{array}{c}6.8 \\
(2.0)\end{array}$ & $2-17$ & $\begin{array}{c}5.7 \\
(1.8)\end{array}$ & $\begin{array}{c}6.6 \\
(2.3)\end{array}$ & $\begin{array}{l}7.6 \\
(2.3)\end{array}$ & $\begin{array}{c}7.4 \\
(1.8)\end{array}$ & $\begin{array}{c}6.0 \\
(1.8)\end{array}$ & $\begin{array}{c}7.9 \\
(1.9)\end{array}$ \\
\hline $\begin{array}{l}\text { Multiple-stemmed } \\
\text { trees }(\%)\end{array}$ & & $\begin{array}{l}17.2 \\
(6.7)\end{array}$ & $9.7-38$ & $\begin{array}{l}14.7 \\
(0.4)\end{array}$ & $\begin{array}{c}22.4 \\
(10.8)\end{array}$ & $\begin{array}{l}21.6 \\
(7.9)\end{array}$ & $\begin{array}{l}14.9 \\
(5.7)\end{array}$ & $\begin{array}{l}13.8 \\
(0.7)\end{array}$ & $\begin{array}{l}15.8 \\
(6.3)\end{array}$ \\
\hline \multicolumn{10}{|l|}{ (b) Diversity } \\
\hline Number of species & 148 & $\begin{array}{l}44 \\
(9)\end{array}$ & $30-58$ & $\begin{array}{l}45 \\
(2)\end{array}$ & $\begin{array}{c}46 \\
(11)\end{array}$ & $\begin{array}{c}38 \\
(11)\end{array}$ & $\begin{array}{c}45 \\
(12)\end{array}$ & $\begin{array}{l}43 \\
(9)\end{array}$ & $\begin{array}{l}48 \\
(3)\end{array}$ \\
\hline Number of genera & 102 & $\begin{array}{l}36 \\
(7)\end{array}$ & $22-51$ & $\begin{array}{l}37 \\
(0)\end{array}$ & $\begin{array}{l}36 \\
(9)\end{array}$ & $\begin{array}{c}30 \\
(11)\end{array}$ & $\begin{array}{l}34 \\
(5)\end{array}$ & $\begin{array}{c}40 \\
(10)\end{array}$ & $\begin{array}{l}40 \\
(2)\end{array}$ \\
\hline Number of families & 42 & $\begin{array}{l}22 \\
(4)\end{array}$ & $16-28$ & $\begin{array}{l}20 \\
(2)\end{array}$ & $\begin{array}{l}24 \\
(5)\end{array}$ & $\begin{array}{l}20 \\
(6)\end{array}$ & $\begin{array}{l}21 \\
(4)\end{array}$ & $\begin{array}{l}23 \\
(4)\end{array}$ & $\begin{array}{l}25 \\
(2)\end{array}$ \\
\hline Shannon Index & & $\begin{array}{c}3.08 \\
(0.33)\end{array}$ & $2.30-3.47$ & $\begin{array}{c}3.17 \\
(0.11)\end{array}$ & $\begin{array}{c}3.08 \\
(0.28)\end{array}$ & $\begin{array}{c}2.69 \\
(0.52)\end{array}$ & $\begin{array}{c}2.99 \\
(0.34)\end{array}$ & $\begin{array}{c}3.19 \\
(0.27)\end{array}$ & $\begin{array}{c}3.33 \\
(0.16)\end{array}$ \\
\hline Simpson Index & & $\begin{array}{l}14.80 \\
(5.12)\end{array}$ & $5.2-24.3$ & $\begin{array}{l}16.3 \\
(2.9)\end{array}$ & $\begin{array}{l}13.8 \\
(4.1)\end{array}$ & $\begin{array}{c}9.7 \\
(6.5)\end{array}$ & $\begin{array}{c}12.49 \\
(4.2)\end{array}$ & $\begin{array}{l}17.0 \\
(3.8)\end{array}$ & $\begin{array}{l}20.0 \\
(4.9)\end{array}$ \\
\hline
\end{tabular}

Table 2. Percent dominance values for the ten dominant tree canopy species in the entire sample and in the different morpho-pedological units where they occur. Dominant species in the entire community account for a large proportion of the total value for all species, but they are not always the most important in the different units, and in some cases, that they are not even present. Abbreviations: SAG = Summit areas on granite; SAT = Summit areas on tuffs; SACG = Summit areas with conglomerates cover on granite; LSG = Low slopes on granite; ISG = Intermediate slopes on granite; HSG = High slopes on granite.

\begin{tabular}{|c|c|c|c|c|c|c|c|}
\hline \multirow[t]{2}{*}{ Species } & \multirow[t]{2}{*}{ All Plots } & \multicolumn{6}{|c|}{ Morpho-pedological units } \\
\hline & & SAG & SAT & SACG & LSG & ISG & HSG \\
\hline Caesalpinia eriostachys & 12.5 & 7.9 & 22.6 & 18.2 & 15.1 & - & 8.5 \\
\hline Gliricidia sepium & 4.3 & 8.1 & - & 0.7 & 4.6 & 7.3 & 6.1 \\
\hline Plumeria rubra & 4.2 & 10.2 & 0.2 & 0.6 & 3.9 & 9.9 & 1.3 \\
\hline Exostema caribaeum & 4.1 & 1.7 & 0.1 & - & 5.6 & 7.4 & 8.5 \\
\hline Lonchocarpus constrictus & 4.1 & 0.4 & 8.8 & 13.1 & 2.3 & 0.5 & 1.8 \\
\hline Caesalpinia coriaria & 3.9 & - & 3.5 & 12.0 & 6.7 & - & - \\
\hline Cordia alliodora & 3.5 & 1.0 & 4.3 & 0.8 & 5.8 & 2.9 & 5.0 \\
\hline Apoplanesia paniculata & 2.7 & 1.7 & 7.9 & 7.9 & 0.4 & - & - \\
\hline Cordia elaeagnoides & 2.7 & - & 2.4 & 7.9 & 5.0 & - & - \\
\hline Psidium sartorianum & 2.7 & 0.8 & 0.3 & 0.1 & 6.4 & 4.2 & 3.0 \\
\hline Sum & 44.9 & 31.7 & 49.9 & 61.3 & 55.8 & 32.1 & 34.2 \\
\hline Total for all species & 148 & 69 & 74 & 68 & 92 & 78 & 85 \\
\hline
\end{tabular}



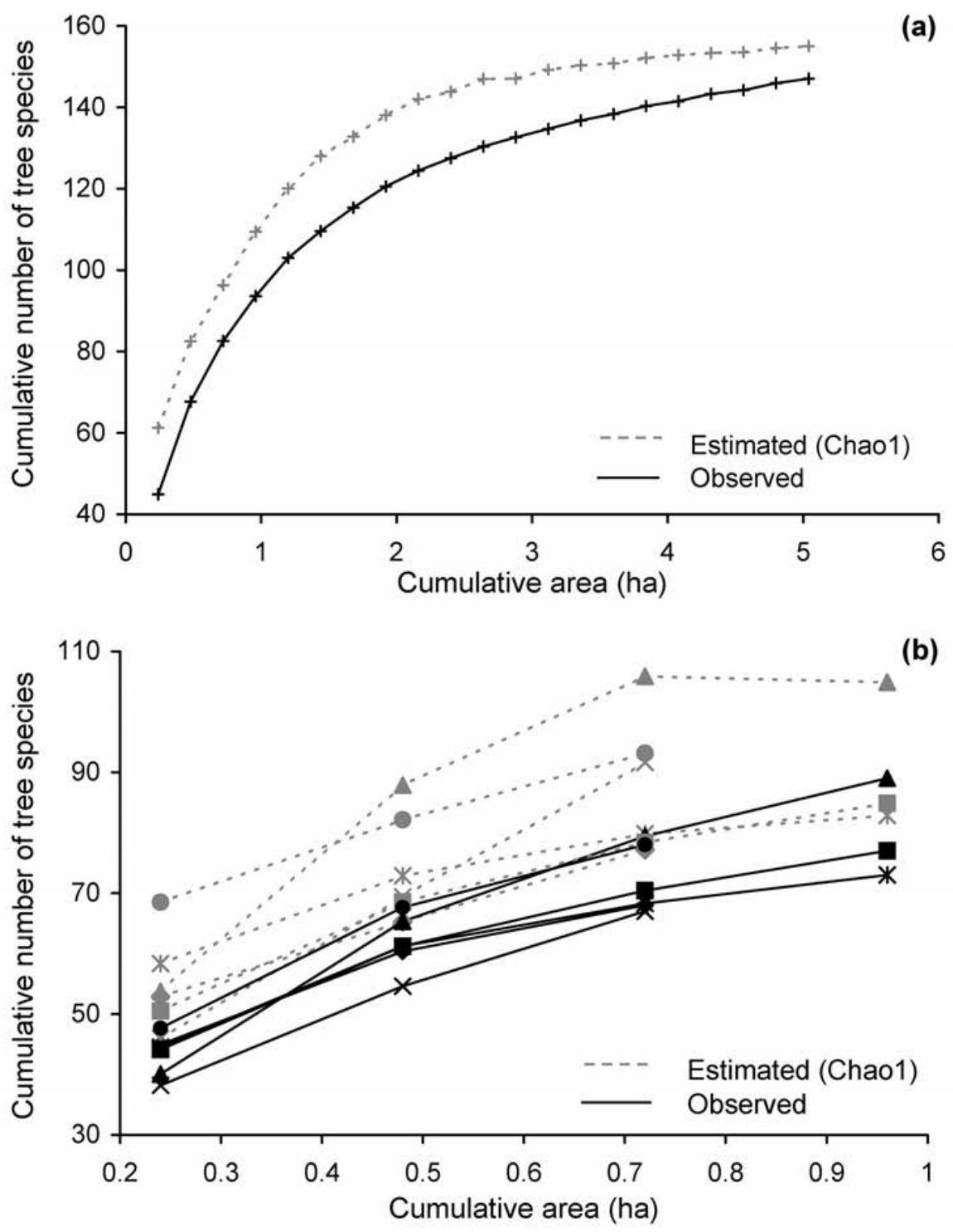

Figure 4. Observed and estimated species-area curves with Chao 1 model. (a) Cumulative species-area curve for 21 plots (total area $=5.04$ ha). (b) Cumulative species-area curve for each morpho-pedological land unit (3 or 4 plots). Symbols and abbreviations: diamond = SAG (Summit areas on granite); asterisk = SAT (Summit areas on tuffs); cross = SACG (Summit areas with conglomerates cover on granite); triangle = LSG (Low slopes on granite); square = ISG (intermediate slopes on granite); circle = HSG (high slopes on granite)

11.45). In contrast, observed and estimated values did not differ significantly in SAG and ISG, suggesting that a surface $<1$ ha is sufficient to represent species richness in them. Different slopes in species-area curves by morphopedological land unit suggested differences, albeit moderate, in the total diversity of each one (figure 4b). SACG was consistently the poorest land unit regarding species richness, while HSG and LSG appeared as the most diverse.

The number of species shared in plot pairs was very variable (range: 4 - 40 species). However, an overall large species turnover ( $\beta$-diversity) was observed in Chamela's TDF, because $50 \%$ of 210 comparisons performed between pairs of plots produced low similarities (Sørensen index $\leq$ 0.25 ), whereas not a single one had a value $>0.75$ (figure 5 ). Frequencies in three similarity categories (low, moderate, high $)$ differed significantly from each other $\left(\chi^{2}=159.2\right.$; $P<0.05)$. In addition, the mean number of shared species between two plots from different lithologies was signifi- 

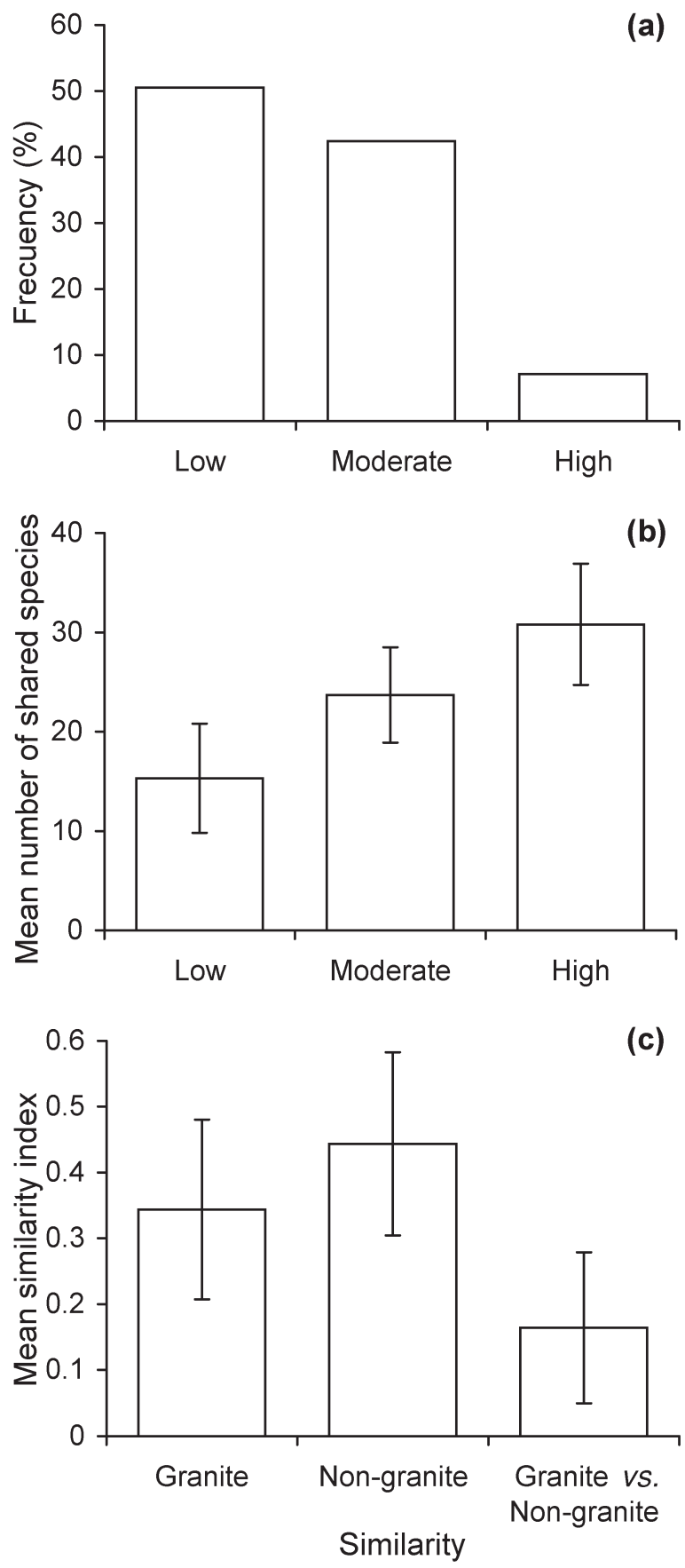

Figure 5. (a) Frequency of the Sørensen index values in three different similarity categories. (b) Mean ( \pm 1 S.D.) number of species shared in different similarity categories. (c) Mean $( \pm 1$ S.D.) similarity values within and between lithologies. cantly smaller than the mean number of shared species by plots from the same lithology, either granite or non-granite $(t=7.80 ; P<0.05)$. The comparison of similarity index values for plot pairs from mixed lithologies and from a single lithology was also significant $(t=10.73 ; P<0.05)$.

PCA ordination showed that plots from the same morpho-pedological land unit were not in close proximity to each other (figures $6 \mathrm{a}, \mathrm{b}$ ). However, significant differences in the scores of plots from granite and non-granite lithology were obtained for the second Principal Component (PC2) based on structural attributes (U = 14; $P<0.05)$, and for the first two axes (PC1 and PC2) based on dominant species $(\mathrm{U}=96$, and $\mathrm{U}=75 ; P<0.05)$. In the structurebased PCA, PC1 and PC2 explained together $69 \%$ of total variance (figure 6a). Plots located on the right (positive) side of PC1 had larger DBH and height means, while those located on the upper (positive) part of PC2 had large dominance values for the five most important species, and they were the least dense and diverse. In contrast, in the PCA based on dominant species, the first two principal components accounted for $32 \%$ of variance. Bourreria purpusii, Comocladia engleriana, Gliricidia sepium, and Plumeria rubra made a major contribution in defining PC1, whereas Bahuinia ungulata, Erythroxylum mexicanum, Cordia alliodora and Croton pseudoniveus took the lead in defining PC2.

\section{Discussion}

Structure and species diversity. Chamela's TDF canopy is essentially dominated by trees, contrasting with other Mexican TDFs, where arborescent columnar cacti stand out among the physiognomic elements (Rzedowski, 1986; Búrquez et al., 1999; Pérez-García et al., 2001). Based on the analysis of trees with DBH $\geq 5 \mathrm{~cm}$, Chamela's TDF may be described as having a moderate to high density ( $>$ 1,000 individuals ha ${ }^{-1}$ ), with a prevailing $\mathrm{DBH}$ of $<10 \mathrm{~cm}$ and a typical inverse $\mathrm{J}$-shaped distribution, a canopy mean height $\leq 10 \mathrm{~m}$, and a minor presence of multi-stemmed trees $(<20 \%)$. In total, 148 tree species were identified, and apparently species diversity was high everywhere (average per plot $=40$ species). Both structural attributes and species diversity estimators displayed spatial differences, and even the dominant species group was variable among sites. Such variability does not seem to be an exclusive character of Chamela, as it has been found in other tropical forest landscape studies (Vázquez-G. and Givnish, 1998; Duivenvoorden and Lips, 1995; Kalacska et al., 2004; Pérez-García et al., 2005).

The spatial variation in tree canopy structure and composition calls out for caution when attempting to extrapolate local particularities to landscape or regional levels. When comparisons between tree communities are performed, the use of unique or mean values for structural and 

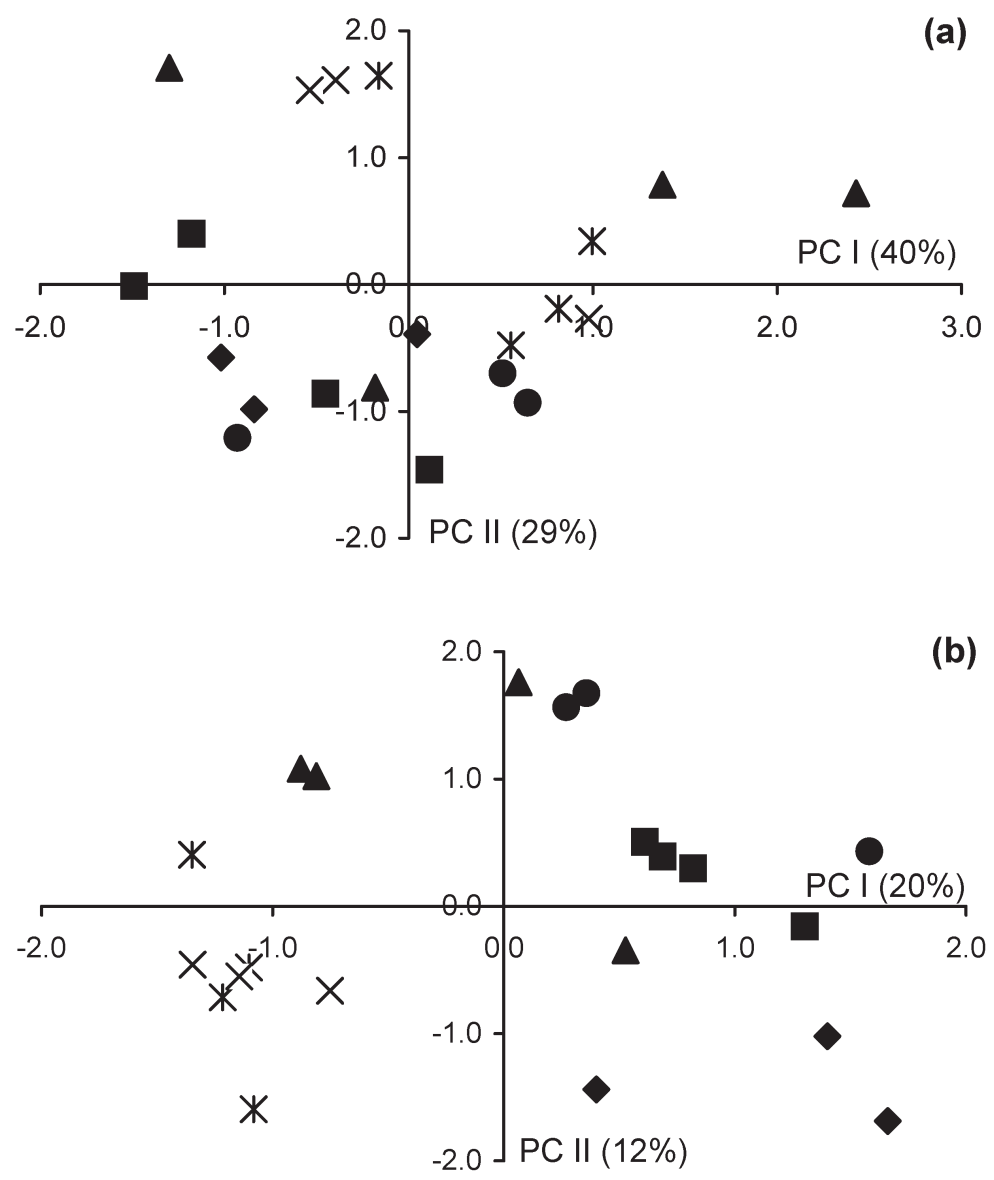

Figure 6. Ordination of plots along two first principal components. (a) PCA based on 15 structural attributes. (b) PCA based on ten dominant species in each plot (63 species). Black symbols correspond to plots on granite, open symbols to plots on non-granite lithology. Symbols and abbreviations: diamond $=$ SAG $($ Summit areas on granite); asterisk $=$ SAT (Summit areas on tuffs); cross $=$ SACG (Summit areas with conglomerates cover on granite); triangle = LSG (Low slopes on granite); square = ISG (intermediate slopes on granite); circle = HSG (high slopes on granite).

diversity variables, as well as generalizations on species composition, should be avoided. Measures of variability, such as standard deviations and ranks, may be much more useful in describing and comparing forest communities (Jongman et al., 1995; Greig-Smith, 1996). Species lists, together with dominance and distributional data, may also provide a better insight of existing patterns of species composition. For example, from the compositional information obtained in this study we have learned about the exclusivity of species such as Apoplanesia paniculata, Caesalpinia coriaria and Lonchocarpus minor on non-granite lithologies, or the presence of Comocladia engleriana, Exostema caribaeum, Gliricidia sepium, and Piptadenia constricta restricted to granite. These results illustrate how more detailed descriptions of vegetation mosaics in tropical forest regions may help identify basic landscape patterns of species distributions (Hubbell and Foster, 1992), and expose fundamental structural and diversity information for tree communities that, undoubtedly, is still incomplete (Chazdon, 1996; Ricklefs, 2000).

Tree canopy landscape pattern. Chamela has been pointed out as one of the most species rich sites among Neotropical TDFs (Gentry, 1988; Trejo-Vázquez, 1998). In less diverse TDFs in Puerto Rico (Murphy and Lugo, 1986), India (Parthasarathy and Karthikeyan, 1997), and Bolivia (Killeen et al., 1998), species-area curves exhibited stability in areas smaller than, or similar to, those we used in this study. In contrast, species-area curves for Chamela did not achieve stability, although they appear to provide a good depiction of total species richness by land unit. Nevertheless, the generalized agreement on the large het- 
erogeneity in the physical conditions of Chamela's landscape warrants the expectation that more species may be added by increasing sampling effort (Galicia et al., 1999; Balvanera et al., 2002; Cotler et al., 2002; Durán et al., 2002).

Landscape-level mosaics in the physical environmental of tropical forests are widely recognized as promoters of habitat heterogeneity, thus enhancing structural and compositional variation in plant communities (Cleef et al., 1982; Campbell, 1994; Condit, 1996; Richards, 1996; Hubbell and Foster, 1992; Gentry and Ortíz-S., 1993; Clark et al., 1995; Búrquez et al., 1999; Wright, 2002). In this study, examination of tree patterns showed that Chamela's TDF canopy was made-up by different assemblages with variable structure and species composition, but above all in dominant species. Structural attributes or species diversity in the plots did not show any obvious relationship with their corresponding morpho-pedological land unit. However, differences in the dominant species group and species turnover ( $\beta$-diversity) were clearly related to lithology (granite $v s$. non-granite). Lithology has been repeatedly pointed out as influencing vegetation heterogeneity across tropical landscapes (Killeen et al., 1998; Lieberman et al., 1996; Tuomisto et al., 1995; Vázquez-G. and Givnish, 1998; Villers et al., 2003; Pérez-García and Meave, 2004, 2006). The ecological role of lithology may reside in its potential to influence soil nutrients, physical and chemical properties, and landforms (Gerrard, 1992). Thus, in addition to the recognition of riparian vs. nonriparian habitats (Lott et al., 1987), and the insolation and elevation gradients within small watersheds (Galicia et al., 1999; Balvanera et al., 2002; Segura et al., 2003) as key factors explaining structural and compositional contrasts in Chamela's TDF, we have shown here the importance of lithology at the landscape level.

TDFs thrive on multiple lithologies (Rzedowski, 1986; Trejo-Vázquez, 1998; Gillespie et al., 2000), and in Mexico continuous TDF canopies are common across mosaics comprising different lithologies (Vázquez-G. and Givnish, 1999; Búrquez et al., 1999; van Devender et al., 2000; Villers et al., 2003; Pérez-García et al., 2005). Therefore, in the absence of intense or chronic anthropogenic disturbances, lithology should be focused on as a key factor in analyzing dominant species of these forests, as well as $\alpha$ - and $\beta$-diversity patterns in tree community studies at landscape and regional levels.

Floristic spatial patterns. Focusing on the floristic patterns at the landscape level, this study showed that Chamela's TDF was diverse not only in species, but also in genera and families. However, no one tree species occurred in all sampled sites and, in contrast to the relative high species richness, only a few species were widely distributed and prevalent in the canopy (appendix 1). The ten dominant species represented a cumulative importance value of $44.9 \%$, with the extreme case being Caesalpinia eriostachys (12.7\%). However, these species were unimportant or even absent from some land units. This pattern was clearly reflected as a high $\beta$-diversity, with the prevalence of low species similarities in the comparisons between plot pairs.

Distribution and abundance patterns of species of Chamela's TDF seems to be influenced by internal and external floristic variation, as many species are shared with other TDF sites. Caesalpinia eriostachys is one example of species found in other Mexican TDFs, e.g. Caleta, Michoacán, and Copalita, Oaxaca (Trejo-Vázquez, 1998), but it was absent from one land unit in Chamela and from another TDF close to Chamela (Vázquez-G. and Givnish, 1992). Other species, such as Ceiba aesculifolia, Lysiloma microphyllum (now L. divaricatum), Hintonia latiflora, and Erythroxylum mexicanum, all of which have been reported as being relatively abundant and widely distributed in Mexican TDFs (Trejo-Vázquez, 1998; Van Devender et al., 2000), were encountered in Chamela, but poorly represented and concentrated in some sites.

Very few genera had many species (Lonchocarpus, Bursera, and Croton). Caesalpinia, a genus with a broad range and important in the structure of other TDFs (Lott and Atkinson, 2002), was noticeable for its abundance and wide distribution across the landscape. In contrast, Tabebuia, Casearia, and Trichilia, all of them widely distributed genera in Neotropical TDFs (Gentry, 1995), were not dominant, nor did they occur in all morpho-pedological land units. According to the number of families, Chamela was comparable to TDFs located elsewhere in Mexico (Trejo-Vázquez, 1998), Costa Rica (Gillespie et al., 2000), and Brazil, Colombia and Venezuela (Sampaio, 1995). Over $40 \%$ of species and genera in Chamela belong in the Leguminosae, Euphorbiaceae and Rubiaceae families; these families are also dominant in other TDFs. Dominance of Leguminosae and Euphorbiaceae is consistent among different Neotropical TDFs (Gentry, 1995; Killeen et al., 1998; Sampaio, 1995; Trejo-Vázquez, 1998; Gillespie et al., 2000; Kalacksa et al., 2004), but not in those from the Paleotropics (Parthasarathy and Karthikeyan, 1997), and Rubiaceae prevailed in a Caribbean island (González and Zak, 1996). Other families, such as Rutaceae and Boraginaceae, are also important in other Mexican (TrejoVázquez, 1998) and Indian TDFs (Parthasarathy and Karthikeyan, 1997).

Common families that are well represented in Chamela and other Neotropical TDFs suggest the existence of a same phytogeographic pattern (Gentry, 1995). Although the presence of common genera and species in Neotropical TDFs was less evident, many such taxa are shared among Mexican TDFs (Vázquez-G. and Givnish, 1992; TrejoVázquez, 1998; Búrquez et al., 1999; van Devender et al., 2000; Lott and Atkinson, 2002; Pérez-García, 2002), sug- 
gesting that Chamela forms an integral part of a large regional flora. In contrast, local patterns of species distributions and abundances may be more closely related to ecological processes, mediated by biotic and abiotic factors and recent history (natural and anthropogenic disturbances).

Our results support the idea of the large heterogeneity of tree communities and species assemblages making up the term tropical deciduous forest in Chamela. Also, they show fundamental phytogeographical and environmental determinants in the characteristics of these tree communities. The complexity of the spatial patterns in these tree communities needs to be better documented with quantitative data on structural attributes, diversity and species dominance, because this information together provides valuable information and helps develop a more realistic understanding of, and sensible comparisons between, seasonally dry tropical forests. Empirical data derived from landscape studies on species composition and abundance patterns are needed in order to test more complex concepts related to tropical plant communities, of which the metacommunity theory is an example (Chase, 2005).

\section{Acknowledgements}

We are grateful to the Chamela Biological Field Station (Universidad Nacional Autónoma de México) for granting permission to carry out this study. Financial support was provided by UNAM (PUMA and PADEP programmes), and by the Mexico-USA cooperation programme (E-198). Miguel Rivas, Jorge Bustamante, Jenny Suárez, Victor Juárez, and Abel Verdusco helped during fieldwork. Logistical assistance was provided by Marco A. Romero. Eduardo A. Pérez-García offered constructive suggestions at the beginning, and Irma Trejo and Alberto Búrquez provided valuable comments on an earlier version of this paper. The Department of Environmental Studies of Florida International University provided facilities to finish the manuscript.

\section{Literature cited}

Ashton M.S., Brokaw N.V.L., Bunyavejchwin R., Chuyong G.B., Co L., Dattaraja H.S., Davies S.J., Esufali S., Ewango C.E.N., Foster R.B., Gunatilleke N., Gunatilleke S., Hart T.H., Hernández C., Hubbell S.P., Itoh A., John R., Kanzaki M., Kenfack D.S., Kiratiprayoon, LaFrankie J.V., Lee H.-S., Liengola I., Makana J.-R., Manokaran N., NavarreteHernández M., Ohkugo T., Pérez R., Pongpattananurak N., Samper C., Sri-ngernyuang K., Sukumar R., Fun I.-F., Sureh H.S., Tan S., Thomas D.W., Thompson J.D., Vallejo M.I., Villa-Munoz G., Valencia R., Yamakura T. and Zimmerman J.K. 2004. Floristics and vegetation of the Forest Dynamics Plots. In: Losos E.C. and Leigh Jr. E.G. Eds. Tropical Forest Diversity and Dynamism: Findings From a Large-Scale Plot
Network, pp. 90-102, University of Chicago Press, Chicago.

Balvanera P., Lott E., Segura G., Siebe C. and Islas A. 2002. Patterns of $\beta$-diversity in a Mexican tropical dry forest. Journal of Vegetation Science 13:145-158.

Bawa K.S., Kress W.J. and Nadkarni N.M. 2004. Beyond paradise: meeting the challenges in tropical biology in the 21 st century. Biotropica 36:276-284.

Bullock S.H. 1986. Climate of Chamela, Jalisco, and trends in the south coastal region of Mexico. Archives of Meteorology, Geophysics and Bioclimatology 36:297-316.

Bullock S.H., Mooney H.A. and Medina E. (Eds) 1995. Seasonally Dry Tropical Forests. Cambridge University Press, Cambridge.

Búrquez A., Martínez-Yrízar A., Felger R.S. and Yetman D. 1999. Vegetation and habitat diversity at the southern edge of the Sonoran Desert. In: Robichaux R.H. Ed. Ecology of Sonoran Desert Plants and Plant Communities, pp. 36-67, University of Arizona, Tucson.

Campbell D.G. 1994. Scale and patterns of community structure in amazonian forests. In: Edwards P.J., May R.M. and Webb N.R. Eds. Large-Scale Ecology and Conservation Biology, pp. 179-197, Blackwell Science, Oxford.

Chase J.M. 2005. Towards a really unified theory for metacommunities. Functional Ecology 19:182-186.

Chazdon R.L. 1996. Spatial heterogeneity in tropical forest structure: canopy palms as landscape mosaics. Trends in Ecology and Evolution 11:8-9.

Clark D.H., Clark D.B., Sandoval R. and Castro M.V. 1995. Edaphic and human effects on landscape-scale distributions of tropical rain forest palms. Ecology 76:2581-2594.

Cleef A.M., Rangel O., van der Hammen T. and Jaramillo R. 1982. The forest vegetation of the Buritaca transect. In: van der Hammen T. and Ruíz P. Eds. La Sierra Nevada de Santa Marta (Colombia), Transecto Buritaca-La Cumbre. Vol. 2, pp. 267406, Studies on Tropical Andean Ecosystems, J. Cramer, Stuttgart.

Colwell R.K. 1997. EstimateS: Statistical Estimation of Species Richness and Shared Species from Samples. Version 5. $<$ http://viceroy.eeb.uconn.edu/estimates >

Condit R. 1996. Defining and mapping vegetation types in megadiverse tropical forests. Trends in Ecology and Evolution 11:4-5.

Connell J.H. 1978. Diversity in tropical rain forest and coral reefs. Science 199:1302-1310.

Cotler H., Durán E. and Siebe C. 2002. Caracterización morfoedafológica y calidad de sitio de un bosque tropical caducifolio. In: Noguera F.A., Vega-Rivera J.H., García-Aldrete N. and Quesada-Avendaño M. Eds. Historia Natural de Chamela, pp. 17-79, Instituto de Biología, Universidad Nacional Autónoma de México, México, D.F.

Delcourt H.R and Delcourt P.A. 1988. Quaternary landscape ecology: relevant scales in space and time. Landscape Ecology 2:23-44.

Duivenvoorden J.F. and Lips J.M. 1995. A Land-Ecological Study of Soils, Vegetation and Plant Diversity in Colombian Amazonia. The Tropenbos Foundation, Wageningen.

Durán E. 2004. Estructura, diversidad y mortalidad del componente arbóreo en un mosaico ambiental de Chamela, México. Ph.D. Dissertation, Universidad Nacional Autónoma de México, México, D.F., 135 pp.

Durán E., Balvanera P., Lott E., Segura G., Pérez-Jiménez A., 
Islas A. and Franco M. 2002. Estructura, composición y dinámica de la vegetación. In: Noguera F.A., Vega-Rivera J.H., García-Aldrete N. and Quesada-Avendaño M. Eds. Historia Natural de Chamela, pp. 443-472, Instituto de Biología, Universidad Nacional Autónoma de México, México, D.F.

Galicia L., López-Blanco J., Zarco-Arista A., Filips V. and García-Oliva F. 1999. The relationship between solar radiation interception and soil water content in a tropical deciduous forest in Mexico. Catena 36:153-164.

García E. 1988. Modificaciones al Sistema de Clasificación Climática de Köppen (Para Adaptarlo a las Condiciones de la República Mexicana). Edited by the author. 4a. ed. México, D.F.

Gentry A.H. 1988. Changes in plant community diversity and floristic composition on environmental and geographical gradients. Annals of the Missouri Botanical Garden 75:1-34.

Gentry A.H. 1995. Diversity and floristic composition of Neotropical dry forest. In: Bullock S.H., Mooney H.A. and Medina E. Eds. Seasonally Dry Tropical Forests, pp. 146-194, Cambridge University Press, Cambridge.

Gentry A.H. and Ortíz-S. R. 1993. Patrones de composición florística de la Amazonia Peruana. In: Kalliola R., Puhakka M. and Danjoy W. Eds. Amazonia Peruana: Vegetación Húmeda Tropical en el Llano Subandino, pp. 155-166, University of Turku and Oficina Nacional de Evaluación de Recursos Naturales, Jyväskylä, Finland.

Gerrard J.G. 1992. Soil Geomorphology: An Integration of Pedology and Geomorphology. Chapman \& Hall, London.

Gillespie T.W., Grijalva A. and Farris C.N. 2000. Diversity, composition, and structure of tropical dry forests in Central America. Plant Ecology 147:37-47.

González O.J. and Zak D.R. 1996. Tropical dry forest of St. Lucia, West Indies: Vegetation and soil properties. Biotropica 28:618-626.

Greig-Smith P. 1996. Application of numerical methods in rain forest. Appendix 2. In: Richards P.W. Ed. The Tropical Rain Forest: An Ecological Study, $2^{\text {nd }}$ ed., pp. 497-502, Cambridge University Press, Cambridge.

Hubbell S.P. 2001. The Unified Neutral Theory of Biodiversity and Biogeography. Princeton University Press, Princeton.

Hubbell S.P. and Foster R.B. 1992. Short-term dynamics of a neotropical forest: why ecological research matters to tropical conservation and management. Oikos 63:48-61.

Jongman R.H.G., Ter Braak C.J.F. and Van Tongeren O.F.R. 1995. Data Analysis in Community and Landscape Ecology. Cambridge University Press, Cambridge.

Kalacska M., Sánchez-Azofeifa A., Calvo J., Quesada M., Rivard B. and Janzen D. 2004. Species composition, similarity and diversity in three successional stages of tropical dry forest. Forest Ecology and Management 200:227-247.

Killeen T.J., Jardim A., Mamani F. and Rojas N. 1998. Diversity, composition and structure of a tropical semideciduous forest in the Chiquitanía region of Santa Cruz, Bolivia. Journal of Tropical Ecology 14:803-827.

Losos E.C., Ashton M.S., Brokaw N.V. L, Bunyavejchwin R., Condit R.S., Chuyong G.B., Co L., Dattaraja H.S., Davies S.J., Esufali S., Ewango C.E.N., Foster R.B., Gunatilleke N., Gunatilleke S., Hart T.H., Hernández C., Hubbell S.P., Itoh A., John R., Kanzaki M., Kenfack D.S., Kiratiprayoon, LaFrankie J.V., Lee H.-S., Liengola I., Lao S., Makana J.-R., Manokaran N., Navarette-Hernández M., Ohkugo T., Pérez R.,
Pongpattananurak N., Samper C., Sri-ngernyuang K., Sukumar R., Fun I.-F., Sureh H.S., Tan S., Thomas D.W., Thompson J.D., Vallejo M.I., Villa-Munoz G., Valencia R., Yamakura T. and Zimmerman J.K. 2004. The structure of tropical forests. In: Losos E.C. and Leigh Jr. E.G. Eds. Tropical Forest Diversity and Dynamism: Findings From a Large-Scale Plot Network, pp. 69-78. University of Chicago Press, Chicago.

Lott E.J. and Atkinson T.H. 2002. Biodiversidad y fitogeografía de Chamela-Cuixmala, Jalisco. In: Noguera F.A., Vega-Rivera J.H., García-Aldrete N. and Quesada-Avendaño M. Eds. Historia Natural de Chamela, pp. 83-97, Instituto de Biología, Universidad Nacional Autónoma de México, México, D.F.

Lott E.J, Bullock S.H. and Solís-Magallanes J.A. 1987. Floristic diversity and structure of upland and arroyo forests of coastal Jalisco. Biotropica 19:228-235.

Maass J.M., Balvanera P., Castillo A., Daily G.C., Money H.A., Ehrlich P., Quesada M., Miranda A., Jaramillo V.J., GarcíaOliva F., Martínez-Yrízar A., Cotler H., López-Blanco J., Pérez-Jiménez A., Búrquez A., Tinoco C., Ceballos G., Barraza L., Ayala R. and Sarukhán J. 2005. Ecosystem services of tropical dry forest: insights from long-term ecological and social research on the Pacific coast of Mexico. Ecology and Society 10:17, published online: < http://www.ecologyandsociety.org/vol10/iss1/art17/>

Magurran A.E. 1990. Ecological Diversity and its Measurement. Princeton University Press, Princeton.

Moreno C.E. 2001. Métodos Para Medir la Biodiversidad. Manuales \& Tesis SEA. Vol. 1, Zaragoza.

Murphy P.G. and Lugo A.E. 1986a. Ecology of tropical dry forest. Annual Review of Ecology and Systematics 17:67-88.

Parthasarathy N. and Karthikeyan R. 1997. Plant biodiversity inventory and conservation of two tropical dry evergreen forests on the Coromandel coast, south India. Biodiversity and Conservation 6:1063-1083.

Pérez-García E.A. 2002. Enclaves de vegetación xerofítica en regiones mésicas: caracterización, análisis de su diversidad florística, e importancia en el mantenimiento de floras xerofíticas. M.Sc. Thesis, Universidad Nacional Autónoma de México, México, D.F., 154 pp.

Pérez-García E.A. y Meave J.A. 2004. Heterogeneity of xerophytic vegetation of limetone outcrops in a tropical deciduous forest region. Plant Ecology 175:147-163.

Pérez-García E.A. and Meave J.A. 2006. Coexistence and divergence of tropical dry forests and savannas in southern México. Journal of Biogeography 33:438-447.

Pérez-García E.A., Meave J. and Gallardo C. 2001. Vegetación y flora de la región de Nizanda, Istmo de Tehuantepec, Oaxaca, México. Acta Botanica Mexicana 56:19-88.

Pérez-García E.A, Meave J.A. and Gallardo-Cruz J.A. 2005. Diversidad $\beta$ y diferenciación florística en un paisaje complejo del trópico estacionalmente seco del sur de México. In: Halffter G., Soberón J., Koleff P. and Melic A. Eds. Sobre Diversidad Biologica: el Significado de las Diversidades Alfa, Beta y Gamma. pp. 123-142. Sociedad Entomológica Aragonesa, Zaragoza.

Richards P.W. 1996. The Tropical Rain Forest: An Ecological Study. 2nd edition, Cambridge University Press, Cambridge.

Ricklefs R.E. 2000. Rarity and diversity in Amazonian forest trees. Trends in Ecology and Evolution 15:83-84.

Rzedowski J. 1986. Vegetación de México. Limusa, México, D.F. 
Sampaio E.V. 1995. Overview of the Brazilian caatinga. In: Bullock S.H., Mooney H.A. and Medina E. Eds. Seasonally Dry Tropical Forests, pp. 35-63, Cambridge University Press, Cambridge.

Segura G., Balvanera P., Durán E. and Pérez-Jiménez A. 2003. Tree community structure and stem mortality along a water availability gradient in a Mexican tropical dry forest. Plant Ecology 169:259-271.

Siegel S. and Castellan N.J. 1995. Estadística no Paramétrica Aplicada a las Ciencias de la Conducta. 4th. ed., Trillas, México, D.F.

Trejo-Vázquez R.I. 1998. Distribución y diversidad de selvas bajas de México: relaciones con el clima y el suelo. Ph.D Dissertation, Universidad Nacional Autónoma de México, México, D.F., 210 pp.

Tuomisto H., Ruokolainen K., Kalliola R., Linna A., Danjoy W. and Rodríguez Z. 1995. Dissecting Amazonian biodiversity.
Science 269:63-66.

van Devender T.R., Sanders A.C., Wilson R.K. and Meyer S.A. 2000. Vegetation, flora, and seasons of the Río Cuchujaqui, a tropical deciduous forest near Alamos, Sonora. In: Robichaux R.H. and Yetman D.A. Eds. The Tropical Deciduous Forest of Alamos, pp. 36-101, Arizona University Press, Tucson.

Vázquez-G. J.A. and Givnish T.J. 1998. Altitudinal gradients in tropical forest composition, structure, and diversity in the Sierra de Manantlán. Journal of Ecology 86:999-1020.

Villers-Ruíz L., Trejo-Vázquez I. and López-Blanco J. 2003. Dry vegetation in relation to the physical environment in the Baja California Peninsula, Mexico. Journal of Vegetation Science 14:517-524.

Wright J.S. 2002. Plant diversity in tropical forest: a review of mechanisms of species coexistence. Oecologia 130:1-14.

Received: February 2, 2006

Corrected version:October 26, 2006

Accepted: November 9, 2006 
Appendix 1. Frequencies of species and morpho-species in the plots of the different morpho-pedological land units. Abbreviations: SAG $=$ Summit areas on granite; SAT $=$ Summit areas on tuffs; SACG $=$ Summit areas with conglomerates cover on granite; LSG = Low slopes on granite; ISG = Intermediate slopes on granite; HSG = High slopes on granite.

\begin{tabular}{llllllll}
\hline Species & Total plots & \multicolumn{4}{c}{ Morpho-pedological land units } \\
\cline { 3 - 6 } & & SAG & SAT & SACG & LSG & ISG & HSG \\
\hline
\end{tabular}

\section{ACHATOCARPACEAE}

Achatocarpus gracilis H.Walter

\section{AMARANTHACEAE}

Lagrezia monosperma (Rose) Standl.

\section{ANACARDIACEAE}

Comocladia engleriana Loes.

Spondias purpurea L.

\section{ANNONACEAE}

Annona palmeri Saff.

Oxandra lanceolata (Swartz) Baill.

Sapranthus violaceus (Dunal) Saff.

\section{APOCYNACEAE}

Alstonia longifolia (A.DC.) Pichon

Plumeria rubra L.

Stemmadenia cf. grandiflora (Jacq.) Miers

Thevetia ovata (Cav.) A.DC.

\section{ARALIACEAE}

Sciadodendron excelsum Griseb.

\section{BIGNONIACEAE}

Crescentia alata Kunth

Swietenia humilis Zucc.

Tabebuia chrysantha (Jacq.) G.Nicholson

T. impetiginosa (Mart. ex DC.) Standl.

\section{BOMBACACEAE}

Ceiba aesculifolia (Kunth) Britten et Baker $\mathrm{f}$.

C. grandifolia Rose

\section{BORAGINACEAE}

Bourreria cf. purpusii Brandegee

Cordia alliodora (Ruiz et Pav.) Oken

C. dentata Poir.

C. elaeagnoides DC.

C. seleriana Fernald

Cordia sp. (n) 
TREE COMMUNITY STRUCTURE AND DIVERSITY IN A TROPICAL DECIDUOUS FOREST LANDSCAPE

\begin{tabular}{|c|c|c|c|c|c|c|c|}
\hline \multirow[t]{2}{*}{ Species } & \multirow[t]{2}{*}{ Total plots } & \multicolumn{6}{|c|}{ Morpho-pedological land units } \\
\hline & & SAG & SAT & SACG & LSG & ISG & HSG \\
\hline \multicolumn{8}{|l|}{ CAPPARACEAE } \\
\hline Capparis indica (L.) Druce & 6 & - & 2 & - & 2 & - & 2 \\
\hline C. verrucosa Jacq. & 1 & - & - & - & 1 & - & - \\
\hline Forchhammeria pallida Liebm. & 8 & - & 3 & 1 & 3 & - & 1 \\
\hline Morisonia americana L. & 1 & - & - & - & - & - & 1 \\
\hline \multicolumn{8}{|l|}{ CARICACEAE } \\
\hline Jacaratia mexicana A.DC. & 7 & - & 3 & 2 & - & 1 & 1 \\
\hline \multicolumn{8}{|l|}{ COCHLOSPERMACEAE } \\
\hline Cochlospermum vitifolium (Willd.) Spreng. & 9 & 3 & - & 1 & - & 4 & 1 \\
\hline \multicolumn{8}{|l|}{ CONVOLVULACEAE } \\
\hline Ipomoea wolcottiana Rose & 18 & 3 & 4 & 2 & 3 & 4 & 2 \\
\hline \multicolumn{8}{|l|}{ EBENACEAE } \\
\hline Diospyros aequoris Standl. & 11 & 3 & 1 & - & 2 & 4 & 1 \\
\hline \multicolumn{8}{|l|}{ ERYTHROXYLACEAE } \\
\hline Erythroxylum mexicanum Kunth & 13 & 1 & 1 & 3 & 3 & 3 & 2 \\
\hline E. rotundifolium Lunan sensu lato & 15 & 2 & 3 & 1 & 3 & 4 & 2 \\
\hline \multicolumn{8}{|l|}{ EUPHORBIACEAE } \\
\hline Adelia oaxacana (Muell.Arg.) Hemsl. & 7 & 3 & - & 1 & 1 & 1 & 1 \\
\hline $\begin{array}{l}\text { Bernardia mexicana (Hook. et Arn.) } \\
\text { Muell.Arg. }\end{array}$ & 1 & - & - & - & - & - & 1 \\
\hline B. spongiosa McVaugh & 1 & - & - & - & - & - & 1 \\
\hline Cnidosculus spinosus Lundell & 4 & 1 & 2 & - & - & 1 & - \\
\hline Croton alamosanus Rose & 6 & - & - & - & 2 & 3 & 1 \\
\hline C. niveus Jacq. & 2 & - & - & - & 1 & 1 & - \\
\hline C. pseudoniveus Lundell & 11 & - & 3 & 1 & 3 & 2 & 2 \\
\hline Croton sp. & 2 & 1 & - & - & - & - & 1 \\
\hline Jatropha chamelensis Pérez-Jim. & 3 & 1 & - & 1 & 1 & - & - \\
\hline J. malacophylla Standl. & 8 & - & 3 & 3 & 1 & 1 & - \\
\hline J. sympetala S.F. Blake et Stand & 3 & - & 3 & - & - & - & - \\
\hline Margaritaria nobilis L.f. & 1 & - & - & - & - & - & 1 \\
\hline Matayba spondioides Standl. & 1 & - & - & - & - & - & 1 \\
\hline Ophellantha spinosa Standl. & 1 & - & - & - & - & - & 1 \\
\hline Pedilanthus calcaratus Schltdl. & 2 & - & - & - & - & 2 & - \\
\hline Phyllanthus botryanthus Müll.Arg. & 3 & - & 1 & - & 1 & 1 & - \\
\hline Sapium pedicellatum Huber & 1 & - & 1 & - & - & - & - \\
\hline \multicolumn{8}{|l|}{ FLACOURTIACEAE } \\
\hline Casearia corymbosa Kunth & 7 & - & 2 & 3 & 2 & - & - \\
\hline C. tremula (Griseb.) Griseb. ex C.Wright & 14 & 2 & 4 & 3 & 3 & 2 & - \\
\hline Prockia crucis P.Browne ex L. & 1 & - & - & 1 & - & - & - \\
\hline Samyda mexicana Rose & 16 & 3 & 3 & 1 & 3 & 4 & 2 \\
\hline \multicolumn{8}{|l|}{ HERNANDIACEAE } \\
\hline Gyrocarpus jatrophifolius Domin & 4 & 1 & 3 & - & - & - & - \\
\hline \multicolumn{8}{|l|}{ JULIANACEAE } \\
\hline Amphipterygium adstringens (Schltdl.) Standl. & 9 & 2 & 3 & 2 & - & 2 & - \\
\hline
\end{tabular}


Elvira Durán, Jorge A. Meave, Emily J. Lott and Gerardo Segura

\begin{tabular}{|c|c|c|c|c|c|c|c|}
\hline \multirow[t]{2}{*}{ Species } & \multirow[t]{2}{*}{ Total plots } & \multicolumn{6}{|c|}{ Morpho-pedological land units } \\
\hline & & SAG & SAT & SACG & LSG & ISG & HSG \\
\hline \multicolumn{8}{|l|}{ LEGUMINOSAE } \\
\hline $\begin{array}{l}\text { Acacia cochliacantha Humb. et Bonpl. } \\
\text { ex Willd. }\end{array}$ & 4 & - & - & 2 & 2 & - & - \\
\hline Acacia sp. & 2 & - & 1 & - & - & 1 & - \\
\hline Albizia occidentalis Brandegee & 3 & 1 & - & - & 1 & 1 & - \\
\hline Apoplanesia paniculata C.Presl & 10 & 1 & 4 & 3 & 2 & - & - \\
\hline Bauhinia ungulata L. & 6 & - & - & - & 1 & 3 & 2 \\
\hline Brongniartia sp. nov. ined. O.Dorado & 7 & 3 & 1 & - & - & 2 & 1 \\
\hline Caesalpinia caladenia Standl. & 6 & 3 & 2 & - & - & 1 & - \\
\hline C. coriaria (Jacq.) Willd. & 10 & - & 4 & 3 & 3 & - & - \\
\hline C. eriostachys Benth. & 14 & 2 & 4 & 3 & 2 & - & 3 \\
\hline C. platyloba S.Watson & 3 & 1 & - & 1 & 1 & - & - \\
\hline C. pulcherrima (L.) Sw. & 4 & - & 3 & 1 & - & - & - \\
\hline C. sclerocarpa Standl. & 11 & - & 3 & 3 & 3 & - & 2 \\
\hline $\begin{array}{l}\text { Calliandra emarginata (Humb. et } \\
\text { Bonpl. ex Willd.) Benth. }\end{array}$ & 1 & - & - & - & - & 1 & - \\
\hline $\begin{array}{l}\text { Chloroleucon mangense (Jacq.) Britton } \\
\text { et Rose var. leucospermum }\end{array}$ & 17 & 2 & 4 & 3 & 3 & 3 & 2 \\
\hline Conzattia multiflora (B.L.Rob.) Standl. & 2 & - & - & - & - & - & 2 \\
\hline Conzattia sp. & 2 & - & - & - & - & 2 & - \\
\hline Dalbergia sp. & 13 & 2 & 2 & 1 & 1 & 4 & 3 \\
\hline Diphysa occidentalis Rose & 6 & - & - & 1 & 2 & 3 & - \\
\hline $\begin{array}{l}\text { Erythrina lanata Rose var. occidentalis } \\
\text { Standl. }\end{array}$ & 10 & 1 & 3 & 2 & 2 & 2 & - \\
\hline Gliricidia sepium (Jacq.) Kunth ex Walp. & 15 & 3 & - & 1 & 4 & 4 & 3 \\
\hline Haematoxylum brasiletto H.Karst. & 3 & 2 & - & - & 1 & - & - \\
\hline Leucaena lanceolata S.Watson & 5 & 1 & 2 & - & 1 & 1 & - \\
\hline Lonchocarpus cochleatus Pittier & 4 & - & 2 & - & 1 & - & 1 \\
\hline L. constrictus Pittier & 18 & 3 & 4 & 3 & 4 & 1 & 3 \\
\hline L. eriocarinalis Micheli & 12 & 3 & 3 & 1 & 1 & 2 & 2 \\
\hline L. guatemalensis Benth. & 3 & - & - & - & 1 & - & 2 \\
\hline L. magallanesii M.Sousa & 3 & 2 & 1 & - & - & - & - \\
\hline L. minor M.Sousa & 5 & - & 4 & 1 & - & - & - \\
\hline L. mutans M.Sousa & 15 & 3 & 3 & - & 3 & 3 & 3 \\
\hline Lonchocarpus sp. 1 & 3 & 2 & - & - & - & - & 1 \\
\hline Lonchocarpus sp. 2 & 2 & 1 & - & - & - & - & 1 \\
\hline Lysiloma microphyllum Benth. & 11 & 2 & 1 & 1 & 3 & 3 & 1 \\
\hline $\begin{array}{l}\text { Pityrocarpa constricta (Micheli et Rose } \\
\text { ex Micheli) J.F.Macbr. }\end{array}$ & 12 & 2 & 1 & - & 2 & 4 & 3 \\
\hline Pithecellobium unguis-cati (L.) Benth. & 5 & - & 1 & 2 & 2 & - & - \\
\hline Poeppigia procera C.Presl & 3 & - & - & - & - & 1 & 2 \\
\hline Pterocarpus sp. & 1 & - & - & - & - & 1 & - \\
\hline Senna atomaria (L.) H.S.Irwin et Barneby & 1 & - & - & - & - & 1 & - \\
\hline \multicolumn{8}{|l|}{ MALPHIGIACEAE } \\
\hline Malpighia ovata Rose & 13 & 1 & 1 & 2 & 3 & 3 & 3 \\
\hline \multicolumn{8}{|l|}{ MELIACEAE } \\
\hline $\begin{array}{l}\text { Trichilia trifolia L. subsp. palmeri (C.DC.) } \\
\text { T.D.Penn. }\end{array}$ & 5 & - & 2 & 1 & 2 & - & - \\
\hline Trichilia sp. & 3 & 1 & - & - & 1 & 1 & - \\
\hline
\end{tabular}


TREE COMMUNITY STRUCTURE AND DIVERSITY IN A TROPICAL DECIDUOUS FOREST LANDSCAPE

\begin{tabular}{|c|c|c|c|c|c|c|c|}
\hline \multirow[t]{2}{*}{ Species } & \multirow[t]{2}{*}{ Total plots } & \multicolumn{6}{|c|}{ Morpho-pedological land units } \\
\hline & & SAG & SAT & SACG & LSG & ISG & HSG \\
\hline \multicolumn{8}{|l|}{ MORACEAE } \\
\hline $\begin{array}{l}\text { Chlorophora tinctoria (L.) Gaudich. ex } \\
\text { Benth. }\end{array}$ & 6 & - & 3 & 2 & 1 & - & - \\
\hline Ficus cotinifolia Kunth & 4 & - & - & 1 & 1 & 1 & 1 \\
\hline \multicolumn{8}{|l|}{ MYRTACEAE } \\
\hline Eugenia rekoi Standl. & 1 & - & - & - & - & - & 1 \\
\hline Psidium sartorianum (O.Berg) Nied. & 15 & 1 & 3 & 1 & 4 & 3 & 3 \\
\hline \multicolumn{8}{|l|}{ NYCTAGINACEAE } \\
\hline Guapira cf. macrocarpa (Miranda) Miranda & 18 & 3 & 3 & 2 & 3 & 4 & 3 \\
\hline \multicolumn{8}{|l|}{ OCHNACEAE } \\
\hline Ouratea mexicana (Humb. et Bonpl.) Engl. & 2 & - & - & - & - & - & 2 \\
\hline \multicolumn{8}{|l|}{ OLACACEAE } \\
\hline Schoepfia sp. & 5 & - & - & - & 2 & 1 & 2 \\
\hline \multicolumn{8}{|l|}{ OLEACEAE } \\
\hline Forestiera cf. rhamnifolia Griseb. & 2 & - & - & - & 1 & - & 1 \\
\hline \multicolumn{8}{|l|}{ ONAGRACEAE } \\
\hline Hauya elegans DC. & 4 & - & - & - & - & 1 & 3 \\
\hline \multicolumn{8}{|l|}{ POLYGONACEAE } \\
\hline Coccoloba liebmannii Lindau & 7 & - & 4 & 2 & 1 & - & - \\
\hline Coccoloba sp. & 8 & 1 & - & - & - & 4 & 3 \\
\hline Ruprechtia fusca Fernald & 10 & 1 & 4 & 3 & 2 & - & - \\
\hline R. pallida Standl. & 2 & - & 1 & 1 & - & - & - \\
\hline \multicolumn{8}{|l|}{ RHAMNACEAE } \\
\hline Colubrina heteroneura (Griseb.) Standl. & 8 & 1 & - & - & 1 & 3 & 3 \\
\hline C. triflora Brongn. ex Sweet & 7 & - & - & 1 & 1 & 2 & 3 \\
\hline Karwinskia latifolia Standl. & 4 & - & - & - & 1 & 1 & 2 \\
\hline \multicolumn{8}{|l|}{ RUBIACEAE } \\
\hline $\begin{array}{l}\text { Allenanthus hondurensis Standl. var. } \\
\text { parvifolia L.Wms. }\end{array}$ & 5 & 3 & 1 & - & - & 1 & - \\
\hline Chiococca alba (L.) Hitchc. & 1 & - & - & - & - & 1 & - \\
\hline $\begin{array}{l}\text { Exostema caribaeum (Jacq.) Roem. et } \\
\text { Schult. }\end{array}$ & 14 & 3 & 1 & - & 3 & 4 & 3 \\
\hline Guettarda elliptica Sw. & 14 & 3 & 2 & 1 & 1 & 4 & 3 \\
\hline $\begin{array}{l}\text { Hintonia latiflora (Sessé et Moc. ex } \\
\text { DC.) Bullock }\end{array}$ & 11 & 1 & 2 & 1 & 3 & 3 & 1 \\
\hline Machaonia acuminata Bonpl. & 4 & 2 & - & - & - & 2 & - \\
\hline Psychotria microdon (DC.) Urb. & 2 & - & - & - & - & - & 2 \\
\hline Randia thurberi S.Watson & 14 & 3 & 2 & 3 & 4 & 2 & - \\
\hline \multicolumn{8}{|l|}{ RUTACEAE } \\
\hline $\begin{array}{l}\text { Esenbeckia berlandieri Baill. ex Hemsl. } \\
\text { subsp. acapulcensis (Rose) Kaastra }\end{array}$ & 5 & - & 2 & - & 1 & - & 2 \\
\hline E. nesiotica Standl. & 9 & 3 & - & - & 2 & 2 & 2 \\
\hline Helietta lottiae F.H.Chiang & 7 & 3 & - & - & 1 & 2 & 1 \\
\hline
\end{tabular}


Elvira Durán, Jorge A. Meave, Emily J. Lott and Gerardo Segura

\begin{tabular}{|c|c|c|c|c|c|c|c|}
\hline \multirow[t]{2}{*}{ Species } & \multirow[t]{2}{*}{ Total plots } & \multicolumn{6}{|c|}{ Morpho-pedological land units } \\
\hline & & SAG & SAT & SACG & LSG & ISG & HSG \\
\hline Zanthoxylum arborescens Rose & 1 & - & - & - & 1 & - & - \\
\hline Z. caribaeum Lam. vel aff. & 5 & 2 & - & - & - & 2 & 1 \\
\hline Z. fagara (L.) Sarg. & 2 & - & - & - & - & - & 2 \\
\hline \multicolumn{8}{|l|}{ SAPINDACEAE } \\
\hline Thouinia paucidentata Radlk. & 6 & - & 3 & 1 & 1 & 1 & - \\
\hline \multicolumn{8}{|l|}{ SAPOTACEAE } \\
\hline $\begin{array}{l}\text { Sideroxylon stenospermum (Standl.) } \\
\text { T.D.Penn. }\end{array}$ & 11 & 3 & - & - & 2 & 3 & 3 \\
\hline \multicolumn{8}{|l|}{ SIMAROUBACEAE } \\
\hline Recchia mexicana Moc. et Sessé ex DC. & 3 & - & - & 1 & 2 & - & - \\
\hline \multicolumn{8}{|l|}{ THYMELEACEAE } \\
\hline Daphnopsis sp. & 1 & - & - & - & - & 1 & - \\
\hline \multicolumn{8}{|l|}{ THEOPHRASTACEAE } \\
\hline Jacquinia pungens A.Gray & 11 & - & 3 & 3 & 3 & 1 & 1 \\
\hline \multicolumn{8}{|l|}{ TILIACEAE } \\
\hline Heliocarpus pallidus Rose & 6 & 1 & 4 & 1 & - & - & - \\
\hline $\begin{array}{l}\text { Luehea candida (Moc. et Sessé ex DC.) } \\
\text { Mart. }\end{array}$ & 9 & 1 & - & 1 & 2 & 3 & 2 \\
\hline \multicolumn{8}{|l|}{ VERBENACEAE } \\
\hline Citharexylum hirtellum Standl. & 1 & 1 & - & - & - & - & - \\
\hline $\begin{array}{l}\text { Citharexylum standleyi Moldenke var. } \\
\text { mexicanum Moldenke }\end{array}$ & 3 & - & 2 & 1 & - & - & - \\
\hline Lippia mcvaughii Moldenke & 5 & - & 3 & - & 2 & - & - \\
\hline \multicolumn{8}{|l|}{ VIOLACEAE } \\
\hline Hybanthus mexicanus Ging. & 2 & - & - & - & - & - & 2 \\
\hline
\end{tabular}

